\title{
Pathophysiology and Management of the Ranula
}

\author{
Bo Hae Kim, Yoon-Jong Ryu, and Young Ho Jung \\ Department of Otorhinolaryngology-Head and Neck Surgery, Boramae Medical Center, \\ Seoul Metropolitan Government-Seoul National University, Seoul National University College of Medicine, Seoul, Korea
}

\section{하마종의 병태생리와 치료}

김보해 · 유윤종 · 정영호

서울대학교 의과대학 보라매병원 이비인후과학교실

\author{
Received February 29, 2016 \\ Revised March 31, 2016 \\ Accepted April 1, 2016 \\ Address for correspondence \\ Young Ho Jung, MD, PhD \\ Department of Otorhinolaryngology- \\ Head and Neck Surgery, \\ Boramae Medical Center, \\ Seoul Metropolitan Government- \\ Seoul National University, \\ Seoul National University \\ College of Medicine, \\ 20 Boramae-ro 5-gil, Dongjak-gu, \\ Seoul 07061, Korea \\ Tel +82-2-870-2445 \\ Fax $+82-2-870-2459$ \\ E-mail entist@naver.com
}

\begin{abstract}
Ranulas are pseudocysts on the floor of the mouth resulting from the retention or extravasation of saliva from the sublingual gland (SLG). The etiology of ranulas is unknown, but they have been associated with local trauma or previous surgery. The anatomic variation of the ductal system of the SLG such as Bartholin's duct might be a possible cause of ranulas. Treatment modalities range from conservative to various surgical techniques, including sclerotherapy, marsupialization, excision of the ranulas with or without excision of the SLG and botox injection. Recently, less invasive treatment modality such as micro-marsupialization has been introduced. It was able to easily and safely treat the ranulas. But it also has the possibility of recurrence, especially in cases having anatomic variation of the ductal system of the SLG. A definitive and reliable treatment choice is surgical resection of the SLG with or without marsupialization than other, more conservative treatments.
\end{abstract}

Korean J Otorhinolaryngol-Head Neck Surg 2016;59(5):339-45

Key Words Anatomic variation $\cdot$ Ranula $\cdot$ Salivary ducts $\cdot$ Sublingual gland.

\section{서 론}

하마종(ranula)은 설하선이나 악하선에서 유출된 점액에 의 하여 생기는 점액 낭종의 일종으로, 주로 구강저에서 발생한 다. 하마종은 19세기 말 Suzanne과 von Hippel이 설하선(sublingual gland)에서 발생하는 것으로 보고한 이후 하마종의 발생과 연관된 다양한 병인들이 밝혀졌다. 설하선의 타액관 이 외상 등에 의해 손상을 입었을 때 주로 발생하며 타액선 및 타액선관의 해부학적 변이 혹은 타액선의 질환으로 인하 여 2차적으로 발생한 타액의 누출로 인하여 발생할 수 있음 이 알려져 있다. 이런 원인들로 인하여 타액선관을 통하여 정 상적으로 타액이 구강으로 배출되지 못하고 주변 연부조직으 로 타액이 누출되고 축적되어 하마종이 발생한다. 임상적으 로 발생 위치에 따라 구강 하마종(oral ranula)과 경부 하마종 (plunging ranula)으로 분류할 수 있는데 동시에 존재하는 경 우(mixed type)도 있다. 구강 하마종의 경우 구강저에 통증 없
는 낭종의 형태로 관찰되며 자세한 문진과 신체 진찰로 대부 분 진단된다. 경부 하마종의 경우 낭종이 악설골근(mylohyoid muscle) 사이로 탈출하여 경부의 종창의 형태를 보이는데 감 별 진단을 위하여 추가적인 검사가 필요하다. 주된 치료 방법 으로는 1962년 Whitlock과 Summergill1)이 설하선 절제로 좋 은 임상 결과를 보고한 이후 설하선의 외과적 절제가 주된 치 료 방법으로 알려져 있다. ${ }^{2)}$ 이외에도 흡인, 조대술 혹은 미세 조대술, 경화 요법 및 보톡스 주사법 등이 소개되었으며 현재 에도 다양한 치료 방법에 대한 비교 연구가 시행되고 있다.

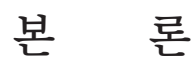

\section{하마종의 형성}

하마종의 병태 생리(Pathophysiology of ranula)

점액낭종(mucocele)이 구강저에 발생하였을 때를 이를 하 
마종이라 한다. 대부분 설하선에서 기원하며 설하선의 외상, 해부학적 변이 혹은 만성 염증성 질환으로 하마종이 발생한 다. 빈도는 낮지만 악하선관이나 소타액선에서 하마종이 기 원하는 경우도 있다. 구강 하마종은 구강저에 투명한 종창의 형태로 주로 발견되는데 조직학적으로 내부에 점도가 높은 점액을 함유하고 낭종의 벽은 혈액이 공급되는 느슨한 섬유 결합조직 혹은 육아조직으로 이루어진다. 낭종벽은 상피화 가 되지 않은 가성낭종으로 정의할 수 있으며 주변으로 경도 의 염증 세포 침윤과 주변 분비관의 확장을 관찰할 수 있다.") 구강 하마종과 경부 하마종은 조직병리학적으로 동일하기 때문에 같은 병변이 다른 임상양상으로 나타나는 것이다.

과거에는 하마종이 발생하는 형태에 따라 타액의 누출에 의해 발생하는 일출형(extravasation type)과 타액의 정체로 인한 정체형(retention type)으로 분류하였다. 이전 연구들은 주로 타액의 정체로 인하여 하마종이 발생한다고 보고하였 으나, Bhaskar 등의 듸옴물연구에서 타액선관을 원위부에서 결 찰하여 타액의 정체를 유발하였을 때에는 점액낭종이 발생 하지 않았고 타액관에 인위적인 손상을 일으켰을 때 점액낭 종이 형성되는 것을 발견하였다. 이 연구를 통하여 현재 하마 종은 타액관의 손상 등에 의한 타액 누출로 인하여 발생한 다고 여겨진다. 다만 타액 정체에 의해서도 하마종이 발생할 수 있는데, 이는 타액의 정체로 인하여 타액을 생산하는 선방 세포들의 압력이 상승하게 되고 압력 상승에 의해 2차적으로 선방 세포가 파괴되어 타액이 누출되는 것으로 생각된다.

타액관에 외상이 발생하면 타액이 누출되고 주변 결체 조 직에 축적된다. 설하선은 다른 주타액선에서 분비되는 타액보 다 점도가 높은 타액을 분비하는데 이는 누출 후 타액의 저류 를 용이하게 하는 원인 중 하나로 생각된다. ${ }^{5)}$ 누출된 타액의 유기질이 대식세포에 의해 분해되고 수분과 비유기물질은 림프관을 통해 흡수된다. 이때 흡수되지 않은 물질에 대한 염 증 반응이 유발된다. 지속적인 염증 반응이 일어나면 결과적 으로 육아조직이 형성되고 육아조직이 성장하면서 상피세포 가 결여된 가성낭종의 벽을 형성한다. 이로 인하여 타액의 누출이 제한되고 가성낭종 자체가 팽창한다. 만약 가성낭종 의 경계로 타액의 누출되는 경우에는 지속적으로 축적되는 타액의 양과 대식세포와 림프관을 통해 제거되는 양이 균형 을 이루게 되는데 이때 하마종은 그 크기를 유지하게 된다.

이런 일련의 과정이 발생한 이후 염증 반응이 지속되면 조 직에 섬유화가 발생하고 주변 타액의 누출을 줄일 수 있다. 악 하선은 주변 조직의 섬유화가 발생하면 악하선의 분비 기능 이 저하되는 것으로 알려져 있는데 설하선의 경우 주변의 섬 유화가 진행하여도 타액 분비 기능이 비교적 잘 유지하는 것 으로 알려져 있다. 이 점은 설하선에서 하마종이 잘 발생하는
원인이며 자연 소실이 적은 이유 중 하나로 생각된다.

설하선의 해부학적 구조(Local anatomy)와 해부학적 변인 (Anatomical variation)

설하선은 구강 점막과 악설곤근 사이에 위치하며 주변으로 피막 없이 느슨한 결합 조직으로 연결되어 있다. 설하선의 후 방은 악하선과 인접하며 간혹 두 타액선과의 경계를 구분하 기 힘든 경우도 있다. 사체 연구에서 설하선은 대설하선(greater sublingual gland)과 소설하선(lesser sublingual gland)으 로 구성되어 있는 것이 알려졌으며, 대설하선은 악하선관 외 측에 존재하고 소설하선의 앞쪽에 위치한다. 대설하선은 절 반 정도에서 존재하지 않거나 혹은 편측만 존재하였다. 소설 하선은 작은 15 30개 정도의 타액선들이 모여 있는 형태로 모든 사체에서 발견되었다. ${ }^{6}$ 설하선에서 생성된 타액은 다수 의 rivinus관을 통하여 구강저로 배출된다.

여러 해부학적 연구에서 1 40\%에서 설하선의 해부학적인 변이가 관찰되었는데 이 중 가장 많은 빈도로 관찰되는 변이 는 설하선의 타액을 배출하는 작은 소관들이 합쳐서 하나의 주타액관을 형성하는 것이다. ${ }^{7)}$ 이를 Bartholin관이라 부르는 데, 하나의 Bartholin관을 이루거나 Bartholin관이 분지를 형 성하여 경우도 있다.) 이 중 Bartholin관이 악하선관(wharton's duct)과 합쳐져 타액을 구강저로 배출하는 경우가 전체 52.9\% 로 가장 높은 빈도를 보인다. 악하선관과 합쳐지지 않고 악하 선관 평행하게 주행하여 설하소구(caruncula sublingualis)를 통하여 구강저로 개구되는 경우도 있다.

본 저자의 연구에서 하마종 이외의 진단으로 설하선을 제거 하였을 때 Bartholin관이 발견된 경우는 없었다(Fig. 1). ${ }^{8)}$ 하지 만 구강 하마종을 수술한 환자에서 $88.9 \%$, 경부 하마종의 치료

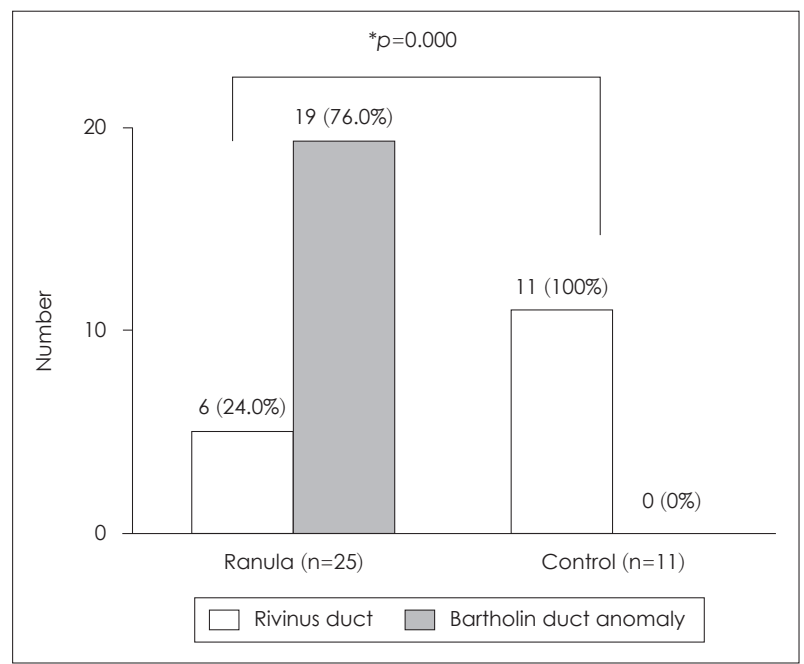

Fig. 1. Ranula cases showed more frequent Bartholin's duct variation than control ( ${ }^{*} p=0.000$, Fisher's exact test). 
를 위하여 설하선을 절제한 환자의 경우 $42.9 \%$ 에서 Bartholin 관이 관찰되었다. ${ }^{8}$ 이는 통계학적으로 유의하게 높은 빈도인 데 설하선에 Bartholin관의 존재가 하마종을 발생시키는 요 인일 될 수 있음을 뒷받침하는 결과로 생각된다.

악설골근의 경우 악하선과 설하선의 경계를 형성하게 되는 데 그 경계가 명확하지 않는 경우도 있다. 주로 근육은 전방 $2 / 3$ 부위에 한 개 이상의 틈이 존재하게 되는데 사체 연구에 서 그 빈도는 33 45\% 정도로 알려져 있다.") 경부 하마종의 경 우 악하선과 악설골근과 설골설근 사이로 탈출하여 발생하 는 경우와 악설골근 전방의 틈을 통하여 탈출하여 경부 하 마종이 발생하는데, 악설골근 전방의 틈이 있는 환자에서 하 마종이 모두 발생하는 것은 아니다. ${ }^{10,11)}$

\section{진단(Diagnosis)}

구강 하마종의 경우 대부분 증상을 유발하지 않으며 크기 가 큰 경우 연하, 발성 및 저작 운동 장애를 유발할 수 있다. 구강 하마종은 자세한 문진과 신체 검진을 통하여 진단이 가 능한데 육안적으로 구강저에 압통을 동반하지 않은 부드러 운 낭종이 관찰된다. 경부 하마종이 의심되는 경우 다른 경부 종양과 감별하여야 한다. 경부 하마종의 경우 $\mathrm{CT}, \mathrm{MRI}$ 및 초 음파가 감별 진단에 이용할 수 있다. ${ }^{12)}$ 다만 구강에만 국한된 하마종이나 크기가 작은 하마종에서는 영상학적 검사는 추 천되지 않는다. ${ }^{13}$

경부 하마종의 경우 CT에서 방사선 투과성이 높은 낭종의 형태로 관찰되는데 설하선에서 기원하여 악설골근을 지날 때까지 꼬리 형태를 가지고 경부로 가면서 크기가 증가한다. $\mathrm{MR}$ 에서는 $\mathrm{T} 1$ 영상에서는 저강도 신호 $\mathrm{T} 2$ 영상에서는 고강 도 신호를 보인다. MR 영상에서도 CT 영상과 유사한 형태 로 관찰되는데 이는 다른 종양과의 감별에 도움이 된다. ${ }^{14)}$ 수 술 후 재발한 환자의 경우 MRI가 CT보다 주변 연부 조직에 대한 구분이 용이하다. ${ }^{15)}$ 초음파에서는 내부 저음영을 보이며 도플러로 관찰하면 낭종 내부에 혈류가 관찰되지 않는다. Jain 등 ${ }^{15)}$ 의 연구에 따르면 소아 환자에서 초음파 소견이 수 술할 때 실제로 관찰되는 병변의 범위 및 양상이 유사함을 주장하였다. 더불어 소아 환자의 경우 검사를 위한 진정을 시 행할 필요가 없으며 방사선 노출이 되지 않는 장점이 있다. 초 음파를 시행하면서 세침흡인검사를 동시에 시행할 수 있는 데 점성이 높은 노란색 점액이 흡인된다. 흡인된 액에서 아밀 라아제(amylase) 분석을 하는 것이 진단에 도움이 될 수 있는 데, 이는 림프관기형에서 수양성 액체가 흡인되는 것과 차이 가 있다.

\section{치료(Treatment)}

\section{단순 관찰(Observation)}

$\mathrm{SeO}$ 등 ${ }^{16}$ 은 $2 \mathrm{~cm}$ 가 넘고 증상을 유발하는 소아 구강 하마 종의 경우 3 개월이 지나도 병변이 소실되지 않음을 보고하였 다. 하지만 소아에서 하마종의 자연 소실이 보고된 경우가 있 으며 추가적인 외상을 줄일 수 있다면 자연 소실 가능성이 있 다고 생각된다. Zhi 등 ${ }^{177}$ 은 소아 하마종의 경우 첫 6 개월간 관 찰하면서 자연적으로 병변이 소실되지 않는 경우에만 수술적 치료를 추천하기도 한다.

흡인/단순 절개 및 배액(Aspiration/incision and drainage)

주사기를 이용하여 단순히 낭종 내부의 타액을 흡인하는 방법으로 매우 간편하여 소아 환자 치료에 사용할 수 있다. Zhi 등 ${ }^{18}$ 은 3 개월 미만의 유아에서 발생한 하마종을 대상으 로 단순 흡인을 시행하였으나 재발률이 $82 \%$ 로 매우 높음을 보고하였다. 비록 합병증은 없었으나 재발이 매우 많아 하마 종의 일반적인 치료방법으로 권고되지 않는다. 다만 유아가 성장할 때까지 보존적인 치료로 사용할 수 있겠다.

단순 절개의 경우는 치료 성공률이 높았던 여러 보고가 있 다. Bonet-Coloma 등 ${ }^{19)}$ 은 소아 환자에서 단순 절개 후 하마 종의 경로를 따라 확장술을 시행하였고 1 년 뒤 $18.2 \%$ 의 재 발을 보고하였다. Takagi 등이의 연구 역시 매우 좋은 치료 결과를 보고하였는데, 경부 하마종의 치료에 구강 하마종 점 막부위에 단술 절개를 가한 후 외부에서 경부 압박을 3 주간 시행하였다. 이는 소아 혹은 신생아를 대상으로 시행한 연구 인데 단순 절개만으로 좋은 치료 결과를 얻을 수 있었던 이 유로 출생 직후 점막 재생능력이 성인보다 더 높기 때문인 것 으로 추정된다.9) 하지만 성인을 대상으로 한 연구에서는 이 보다 높은 재발률을 보고했는데 이는 절개 부위가 상피가 자라기 전에 일찍 유합되거나 혹은 타액이 저류되어 있는 부 위에 적절한 섬유화가 일어나지 않기 때문인 것으로 생각된 다. 현재 임상적 이용은 설하선을 절제할 때 동시에 시행할 수 있는 방법으로 생각된다. ${ }^{17)}$

\section{조대술(Marsupialization)}

조대술의 경우 비교적 비침습적인 치료 방법으로 구강과 낭종의 내부를 하나의 공간으로 만드는 치료이다. 구강에서 관찰되는 낭종벽을 최대한 제거하고 내부의 점액을 제거한 후 제거된 낭종의 경계와 주변 점막을 봉합하는 방법으로 하 마종 저부와 구강저 점막이 연속되도록 한다. 실제로 조대술 을 단독으로 시행하였을 때 재발률은 14 67\%로 매우 다양 하게 보고되었으나 레이저를 이용하여 하마종의 저부에 레 
이저를 조사하였을 때 재발은 현저하게 줄일 수 있었다. ${ }^{21,22)}$ 이는 레이저를 조사한 이후 낭종의 저부에서 적절하게 섬유 화 과정이 진행되는 것으로 타액 누출이 중단되는 것으로 생 각된다. 변형된 방법 중 다른 하나는 Baurmash ${ }^{23,24)}$ 가 시행한 방법으로 조대술을 시행한 후 하마종이 있던 공간에 거즈를 충전하는 방법이다. 충전을 통하여 설하선을 직접 압박하여 타액 누출을 방지하고 거즈에 대한 염증 반응으로 주변에 섬 유화 반응이 활발하게 일어나기 때문에 재발률을 10 43\%로 줄일 수 있음을 보고하였다. 여러 연구를 종합해보면 단순 혹은 변형 조대술을 시행한 경우 재발률은 $20 \%$ 정도이며 만 약 재발한 경우 설하선을 제거하는 것이 좋은 방법이다. ${ }^{2)}$

조대술은 비교적 덜 침습적이기 때문에 소아를 대상으로 시행한 연구도 많다. Yuca 등 ${ }^{25)}$ 의 후향적 연구에서 소아 환자 를 대상으로 조대술을 시행하였을 때 9예 중 1 예에서만 재발 하였으며 Bonet-Coloma 등 ${ }^{19)}$ 의 연구에서도 $8.6 \%$ 에서만 재발 하였다. 이 결과들을 살펴 보았을 때 조대술은 소아 환자에서 유용한 치료방법으로 생각된다.

\section{경화치료(Sclerotherapy)}

경화치료는 염증을 유발할 수 있는 물질을 가성낭종 내부 공간에 주입하고 섬유화를 유도하는 치료 방법이다. 주로 벤질 페니실린(benzylpenicillin)에서 배양된 streptococcus pyogenes의 약독화 종으로부터 분리한 $\mathrm{OK}-432$ (picibanil)를 사용 한다. OK-432는 일본에서 항암제로 처음 사용되었으며 1987 년 Ogita 등에 의해 처음으로 경화치료에 사용되었다. OK-432 를 주입하면 경화물질 주변으로 염증세포들이 침윤하고 염 증 사이토카인이 분비되는데 이로 인하여 혈관 내피세포의 투 과성이 증가하고 체액 흐름이 증가하여 2차적으로 섬유화가 발생한다.

$\mathrm{Roh}^{26)}$ 의 전향적 연구에 따르면 경화치료를 이용하여 $74 \%$ 의 치료 성공률을 보고하여 수술할 때 발생할 수 있는 설하선 의 손상을 유발하지 않으면서도 수술적 치료와 동등한 결과 를 얻을 수 있어 경화치료가 초 치료로 사용될 수 있음을 주 장하였다. 다만 주입횟수는 1 5회로 평균적으로 2회 이상의 반복적인 시술이 필요한 경우가 많았다. 다른 연구들의 결과 를 살펴보면 치료 성공률은 수술적 치료와 유사하거나 혹은 조금 낮은 것으로 생각된다. 많은 연구들에서 구강 하마종에 서도 경화치료가 좋은 결과를 보이기 때문에 우선 경화치료 를 시행하고 이후 치료가 되지 않을 경우 설하선 절제 등의 수술적 치료를 추천하였다. ${ }^{26,27)}$ 실제로 본 저자의 경험에서도 이전 경화치료를 시행받았던 5명 환자들에서 수술 후 치료 결 과의 차이는 관찰되지 않았다.

경화술은 구강 하마종에 비해 경부 하마종이 성공률이 높
은데, 이는 경화 물질의 주입 후 주입부로의 누출 정도의 차 이 때문인 것으로 생각된다. 구강 하마종의 경우가 경화 물질 이 구강 내에 머물기 때문에 누출 정도가 많다. 경화치료를 할 때 $\mathrm{OK}-432$ 가 주변 조직으로의 누출로 되면 통증 및 연 하곤란을 유발할 수 있고 전신적으로 고열 등의 합병증이 발 생할 수 있음을 유념하여야 한다. 경화치료법은 간단하게 소 개하면 부분 마취를 시행한 후 병변 부위에서 가능한 많은 양의 타액을 흡인한다. 이후 $\mathrm{OK}-4320.1 \mathrm{mg}$ 을 $10 \mathrm{~mL}$ 생리식 염수에 녹여 흡인한 타액과 동일한 양을 낭종 내부에 주입한 다. 이때 $0.2 \mathrm{mg}$ 을 초과하지 않도록 하고 이때 흡인 혹은 주 입 부위로 $\mathrm{OK}-432$ 가 누출되지 않도록 낭종과 거리를 두어 점막하 공간을 통한 흡인과 주입이 이루어 지는 것이 추천된 다. 하마종의 치료에 OK432를 이용한 국내 연구도 많으며 좋은 결과를 보고하였지만, 현재 $\mathrm{OK}-432$ 는 단종되어 임상적 으로 사용하기에는 한계가 있다. ${ }^{28,29)}$

이외 질산은(silver nitrate)을 하마종 내부로 주입하는 방법 으로 질산은이 조직을 응고시키고 이로 인하여 염증 반응을 유발하는 방법인데 7증례 중 3증례에서 하마종을 성공적으 로 치료하였다. ${ }^{30)}$ 이외 국내에서 $99 \%$ 알코올을 이용하여 경 화술을 치료한 예도 보고되었다. ${ }^{31)}$

\section{보톡스 주사(Botox injection)}

보톡스는 타액선에 존재하는 콜린성 부교감신경 말단에 작 용하여 신경전달물질의 방출을 억제한다. 기존 증례를 살펴보 면 낭종에서 50 75 unit의 보톡스(type A)를 낭종 내부와 설 하선 모두에 주입하였으며 주입 후 재발이 관찰되지 않았다. 이는 수술적 치료에서 발생할 수 있는 신경 손상, OK-432를 이용한 경화치료 후 발생할 수 있는 고열 등의 부작용이 없이 하마종을 치료한 보고이다. ${ }^{32,33)}$

보톡스의 치료 기전에 대하여 살펴보면 이전 동물 연구에서 타액관을 결찰한 후 부교감신경을 절단하였을 때 타액 배출 이 줄고 결과적으로 설하선이 위축되는 것이 관찰할 수 있었 는데 보톡스 역시 화학적으로 타액선의 위축을 초래하여 치료 가 될 것으로 생각된다. 쉽고 간편한 치료법이나 시행 후 재발 여부에 대한 장기간의 추적관찰 연구가 없어 추가적인 연구가 필요하겠다.

\section{미세조대술(Micromarsupialization)}

미세조대술은 1995년 Morton과 Bartley ${ }^{34}$ 에 의해 비교적 최근에 소개된 술식이다. 현재까지 매우 높은 치료 성공률이 보고되었으며, 단지 점막에만 봉합을 하는 방법으로 설신경 의 손상 위험 없이 하마종을 치료할 수 있어 매우 유용한 치 료법으로 알려져 있다. 더불어 전신마취가 없이 외래에서 짧 
은 시간에 시행할 수 있어 경제적인 장점이 있다. 이런 장점으 로 최근 미세조대술의 사용 빈도가 높아지고 있고 이와 연관 된 많은 연구들이 발표되고 있다.

문헌에 소개된 방법을 간단하게 소개하면 xylocaine 등을 이용하여 점막 마취를 시행한 후 병변의 장축을 따라 1 회의 봉합을 시행한다. 봉합 후 항생제 혹은 비스테로이드성 소염 제를 사용하지 않고 1 주째 재방문 후 봉합사를 제거한다. 이 때 병변이 지속되거나 짧은 시간 내에 재발하면 봉합 횟수를 늘려 다시 시행하고 2주 뒤에 봉합사를 제거한다. ${ }^{35)}$

미세조대술의 이론적 배경은 하마종의 구강 측 점막에 봉 합사를 이용하여 봉합을 시행하면 하마종 내부의 타액이 봉 합사와 점막 사이로 누출되게 되고 점막상피가 봉합사를 따 라 성장하면서 타액의 누출로를 생성하게 된다. 따라서 타액 이 지속적으로 배액되고 낭종 내 압력이 낮아지고 결과적으 로 Rivinus관이 점막에 연결되어 새로운 타액 배액 경로를 생 성하게 되는 것이다. 더불어 봉합사에 대한 염증 반응이 유도 되어 하마종의 위축을 기대할 수 있다.935) 국소 마취로 시행 가 능하며 시술 시간이 짧고 부작용이 거의 발생하지 않았다. ${ }^{35)}$ 간편하여 소아 환자에도 적용할 수 있으며 재발하였을 때에 도 다시 시행할 수 있다. 통증이 적고 외래에서 시행할 수 있어 환자의 순응도도 역시 높다. 하지만 이 치료법은 임상적 진단 에 기반을 두고 시행되기 때문에 조직 검사를 시행할 수 없으 며 봉합 후 봉합사를 따라 상피세포가 충분하게 성장하지 않 는다면 하마종이 재발할 수 있다.

하지만 현재 재발에 대한 장기간의 추적 관찰 결과에 대한 데이터가 부족하고 많은 환자를 대상으로 시행한 전향적 연구 결과가 더욱 축적되어야 그 유용성에 대하여 평가할 수 있겠다.

\section{하마종 절제술(Ranula excision)}

하마종의 인접한 점막 절개를 가한 후 내부의 가성낭종을 적출하고 점막을 다시 봉합해주는 방법이다. 최근에는 하마 종만 단독 절제하고 그 결과를 평가한 연구는 보고되지 않았 다. Patel 등 ${ }^{2}$ 의 연구에 따르면 하마종 단독 절제 후 $12 \%$ 의 재 발을 보고하였으나 Zhao 등 ${ }^{3)}$ 의 연구에서는 재발률이 $58 \%$ 였 다. 따라서 이 치료법을 단독으로 사용한 경우의 효과는 추정 하기 어렵다. 다만 병인을 고려하였을 때 하마종의 표준 치료 로 시행하기에는 근거가 부족하며 설하선 제거를 시행할 때 동시에 사용할 수 있겠다.

설하선 절제(Sublingual gland excision with or without ranula excision)

설하선을 절제하는 방법은 가장 재발이 적어 구강 및 경부 하마종의 표준 치료로 사용되고 있다. ${ }^{2,8,9)}$ 하마종을 동시에
절제하는 경우는 구강 하마종의 경우 점막 절개를 가한 후 하 마종과 주변의 설하선을 동시에 제거해 주는 방법이다. 이 치 료법은 하마종의 원인인 설하선과 동반된 병변을 함께 제거 하는 방법으로 구강 하마종과 경부 하마종 모두에서 시행 가 능하다.

설하선 절제할 때 혈관성 출혈, 설신경의 손상 및 악하선관 의 손상을 발생할 수 있다. 따라서 악하선관과 설하선 내측 경계를 박리할 때 유의하여야 한다. 수술 중 설신경 손상을 최소화 하기 위하여 설하선 부분 절제만을 시행한 경우도 있 는데, MeGurk 등은 재발 없이 하마종을 치료할 수 있음을 보 고 하였다. 하지만 Harrison ${ }^{9}$ 은 설하선을 제거한 후 하마종 이 재발한 것은 설골상근의 틈에 존재하는 잔존 설하선에 의 해 발생한다고 하였다. 따라서 설하선 전절제술이 재발을 줄 이기 위한 적절한 술식으로 생각된다. 철저한 하마종의 낭종 벽 절제 없이 설하선을 절제하여도 충분한 치료 결과를 얻을 수도 있다고 알려져 있는데 경부 하마종의 경우 설하선만 절 제하고 낭종을 배액해주는 것으로도 충분한 치료 효과를 기 대할 수 있다는 보고가 있다. 하지만 설하선 단독 절제와 설 하선과 하마종을 동시에 절제한 경우를 비교한 연구는 없다. 다만 하마종을 동시에 절제한 경우 검체에서 가성낭종을 확인 할 수 있는 장점이 있다. 경부 하마종을 절제할 때 구강 접근 법과 경부 접근법을 동시에 사용할 수 있는데, 이 경우 합병증 이 $37 \%$ 보고된 반면 경구 접근법을 시행한 경우 $4 \%$ 에서만 합 병증이 관찰되었다. ${ }^{36)}$ 최근 들어 구강 내 하마종과 설하선 절 제를 로봇을 이용하여 시행한 보고도 있다. 수술 시야가 좋 으며 확대된 고화질의 영상을 보면서 수술을 진행하기 때문 에 악화선관 및 설신경 손상을 최소화할 수 있다고 생각되나 시술 비용이 높아 일반적인 치료로 사용하기에는 그 한계가 있겠다.

본 저자의 경우 설하선을 절제할 때 우선 악하선관을 원위 부를 확인한 이 후 근위부 방향으로 박리를 진행한다. 설하선 박리 중에 설신경을 확인하고 설하선은 악하선과 분리하여 손상 가능성을 최소화한다. 필요에 따라 하마종을 같이 절제 하고 마지막으로 악하선관과 설신경이 노출되지 않도록 봉합 을 시행하였다. 설하선을 절제하여 구강 및 경부 하마종 모두 에서 좋은 치료 결과를 얻었다.

본 저자는 하마종 발생 원인 중 해부학적 변이의 정도를 평 가 하기 위하여 연구를 시행하였다. 특히 설하선에 주타액관인 Bartholin관이 존재하고 악하선관으로 배액되는 변이를 수 술 중 관찰되는 소견과 수술 후 검체를 이용하여 평가하였 다. 대조군의 경우 다른 원인으로 설하선을 제거한 환자로 하 고 하마종의 치료를 위해 설하선을 절제한 경우의 환자들과 해부학적 변이 정도의 차이를 분석하였다. 실제로 연구 결과 
하마종 환자군에서 Bartholin관의 변이가 많은 빈도로 발견 되었으며 통계학적으로도 유의하게 높은 빈도였다(Fig. 1). ${ }^{8}$ 따라서 Bartholin관이 존재하고 악하선관과 합쳐지는 해부 학적 변이는 하마종 발생의 한 원인으로 생각된다. 다만 변이 가 관찰되는 모든 환자에서 하마종이 발생하지는 않았다. 발 생 기전으로는 악하선에서 생산된 타액의 양이 많기 때문에 Bartholin관이 악하선관과 직접 문합되어 있을 경우 설하선 에서 생산된 타액이 적절하게 배출되지 못하고 이로 인하여 기능적인 타액 정체가 발생한다. 이로 인하여 선방 세포 내 압 력이 증가하고 선방세포가 파괴되어 하마종이 발생할 것으로 생각된다. 수술 중 Bartholin관을 적절하게 결찰하는 것이 중 요한데 편측만 결찰하였을 경우 악하공간에 타액의 저류가 발생할 수 있다. 본 저자는 수술 중 실제로 Bartholin관이 관찰 되면 주의깊게 박리한 이 후 양측에서 Bartholin관을 결찰하 였는데, 이는 수술 후 악하선 주변에 타액이 저류되고 하마종 이 재발하는 것 예방하기 위하여 필수적으로 시행되어야 한다.

\section{결 론}

하마종은 타액의 누출로 인하여 구강저에 발생하는 점액 낭종으로 다양한 치료 방법이 소개되었다. 최근 미세조대술 과 같이 매우 침습도가 낮은 치료 방법들이 소개되었고, 쉽고 안전하게 하마종을 치료할 수 있게 되었다. 하지만 이런 치료 들 역시 재발의 가능성이 있다. 현재 설하선의 제거가 하마종 의 주된 치료법이며 본 저자의 연구에서도 구강 및 경부 하마 종 모두에서 설하선 제거 후 좋은 치료 결과를 얻었다.

더불어 하마종 환자 중 설하선에 주타액관이 존재하는 변 이의 빈도가 높았으며 있으며 특히 Bartholin관이 악하선관 과 합쳐져 구강저로 배액되는 경우가 많이 발견되었다. 따라서 이런 해부학적 변이가 하마종의 발생 요인 중 하나로 생각되 며 변이를 가지고 있는 환자의 설하선을 제거할 때 Bartholin 관을 충분하게 노출시킨 후 양측에서 결찰하는 것이 수술 후 재발을 줄일 수 있겠다.

\section{REFERENCES}

1) Whitlock RI, Summergill GB. Ranula with cervical extension. Report of a case. Oral Surg Oral Med Oral Pathol 1962;15:1163-71.

2) Patel MR, Deal AM, Shockley WW. Oral and plunging ranulas: what is the most effective treatment? Laryngoscope 2009;119(8):1501-9.

3) Zhao YF, Jia Y, Chen XM, Zhang WF. Clinical review of 580 ranulas. Oral Surg Oral Med Oral Pathol Oral Radiol Endod 2004;98(3): 281-7.

4) Bhaskar SN, Bolden TE, Weinmann JP. Pathogenesis of mucoceles. J Dent Res 1956;35(6):863-74.

5) Davison MJ, Morton RP, McIvor NP. Plunging ranula: clinical observations. Head Neck 1998;20(1):63-8.

6) Zhang L, Xu H, Cai ZG, Mao C, Wang Y, Peng X, et al. Clinical and anatomic study on the ducts of the submandibular and sublingual glands. J Oral Maxillofac Surg 2010;68(3):606-10.

7) Chen CJ, Guo P, Chen XY. Recurrent sublingual ranula or saliva leakage from the submandibular gland? Anatomical consideration of the ductal system of the sublingual gland. J Oral Maxillofac Surg 2015;73(4):675.el-7.

8) Mun SJ, Choi HG, Kim H, Park JH, Jung YH, Sung MW, et al. Ductal variation of the sublingual gland: a predisposing factor for ranula formation. Head Neck 2014;36(4):540-4.

9) Harrison JD. Modern management and pathophysiology of ranula: literature review. Head Neck 2010;32(10):1310-20.

10) Nathan H, Luchansky E. Sublingual gland herniation through the mylohyoid muscle. Oral Surg Oral Med Oral Pathol 1985;59(1):21-3.

11) Mair IW, Schewitsch I, Svendsen E, Haugeto OK. Cervical ranula. J Laryngol Otol 1979;93(6):623-8.

12) Samant $S$, Morton RP, Ahmad Z. Surgery for plunging ranula: the lesson not yet learned? Eur Arch Otorhinolaryngol 2011;268(10): $1513-8$.

13) Lee DH, Yoon TM, Lee JK, Lim SC. Treatment outcomes of the intraoral approach for a simple ranula. Oral Surg Oral Med Oral Pathol Oral Radiol 2015;119(4):e223-5.

14) Edwards RM, Chapman T, Horn DL, Paladin AM, Iyer RS. Imaging of pediatric floor of mouth lesions. Pediatr Radiol 2013;43(5):523-35.

15) Jain R, Morton RP, Ahmad Z. Diagnostic difficulties of plunging ranula: case series. J Laryngol Otol 2012;126:506-10.

16) Seo JH, Park JJ, Kim HY, Jeon SY, Kim JP, Ahn SK, et al. Surgical management of intraoral ranulas in children: an analysis of 17 pediatric cases. Int J Pediatr Otorhinolaryngol 2010;74(2):202-5.

17) Zhi K, Gao L, Ren W. What is new in management of pediatric ranula? Curr Opin Otolaryngol Head Neck Surg 2014;22(6):525-9.

18) Zhi K, Wen Y, Ren W, Zhang Y. Management of infant ranula. Int J Pediatr Otorhinolaryngol 2008;72(6):823-6.

19) Bonet-Coloma C, Minguez-Martinez I, Aloy-Prósper A, Galán-Gil S, Peñarrocha-Diago M, Mínguez-Sanz JM. Pediatric oral ranula: clinical follow-up study of 57 cases. Med Oral Patol Oral Cir Bucal 2011;16(2):e158-62.

20) Takagi S, Mizukawa N, Kimura T, Asaumi JI. Treatment of a plunging ranula with fenestration and continuous pressure. Br J Oral Maxillofac Surg 2003;41(6):410-3.

21) Mintz S, Barak S, Horowitz I. Carbon dioxide laser excision and vaporization of nonplunging ranulas: a comparison of two treatment protocols. J Oral Maxillofac Surg 1994;52(4):370-2.

22) Niccoli-Filho W, Morosolli AR. Surgical treatment of ranula with carbon dioxide laser radiation. Lasers Med Sci 2004;19(1):12-4.

23) Baurmash HD. Treating oral ranula: another case against blanket removal of the sublingual gland. Br J Oral Maxillofac Surg 2001; 39(3):217-20.

24) Baurmash HD. Implant surgery and a plunging ranula. J Oral Maxillofac Surg 2007;65(9):1901-2.

25) Yuca K, Bayram I, Cankaya H, Caksen H, Kiroğlu AF, Kiriş M. Pediatric intraoral ranulas: an analysis of nine cases. Tohoku J Exp Med 2005;205(2):151-5.

26) Roh JL. Primary treatment of ranula with intracystic injection of OK-432. Laryngoscope 2006;116(2):169-72.

27) Fukase S, Ohta N, Inamura K, Aoyagi M. Treatment of ranula wth intracystic injection of the streptococcal preparation OK-432. Ann Otol Rhinol Laryngol 2003;112(3):214-20.

28) Kim HS, Roh JL. Sclerotherapy of ranula with intracystic injection of OK-432. Korean J Otolaryngol-Head Neck Surg 2006;49(10): 1003-7.

29) Kim MG, Cho EY, Song JW. The effect of the sclerotherapy of plunging ranula with the use of picibanil. Korean J OtolaryngolHead Neck Surg 2004;47(12):1278-81.

30) Takimoto T, Sato T, Umeda R. Reevaluation of treatment of ranula. 
Auris Nasus Larynx 1989;16(3):165-8.

31) Kim MG. The effectiveness of the sclerotherapy of benign neck cyst with the use of OK-432 and 99\% alcohol. Korean J OtolaryngolHead Neck Surg 2005;48(9):1154-60.

32) Capaccio P, Cuccarini V, Benicchio V, Minorati D, Spadari F, Ottaviani F. Treatment of iatrogenic submandibular sialocele with botulinum toxin. Case report. Br J Oral Maxillofac Surg 2007;45(5):415-7.

33) Chow TL, Chan SW, Lam SH. Ranula successfully treated by botulinum toxin type A: report of 3 cases. Oral Surg Oral Med Oral
Pathol Oral Radiol Endod 2008;105(1):41-2.

34) Morton RP, Bartley JR. Simple sublingual ranulas: pathogenesis and management. J Otolaryngol 1995;24(4):253-4.

35) Woo SH, Chi JH, Kim BH, Kwon SK. Treatment of intraoral ranulas with micromarsupialization: clinical outcomes and safety from a phase II clinical trial. Head Neck 2015;37(2):197-201.

36) Kobayashi T, Ochi K, Komatsuzaki Y, Sugiura N, Saito S. Blanket removal of the sublingual gland for treatment of plunging ranula. Laryngoscope 2003;113(2):386-8.

\section{정답 및 해설}

답 (3)

해 설 Supralabyrinthine space 및 otic capsule medial side를 침범하는 petrous bone cholesteatoma이다. Labyrinthine 이 나 geniculate 부위를 흔히 침범하여 안면신경마비를 일으킨다. 이 증례의 경우 환자의 잔청이 없고 병변의 완벽한 제거 를 위해서 otic capsule을 제거하는 것이 필요하다. 